\section{A unique patch of timberline ecotone with three species of Lady's slipper orchids in Garhwal Himalaya, India}

\author{
Ishwari D. Rai ${ }^{1}$, Bhupendra S. Adhikari ${ }^{2}$ \& \\ Gopal S. Rawat ${ }^{1}$
}

1,2 Department of Habitat Ecology, Wildlife Institute of India, P.O. Box 18, Chandrabani, Dehradun, Uttarakhand 248001, India Email: ${ }^{2}$ adhikaribs@wii.gov.in (corresponding author)

The timberline forms one of the most prominent ecological boundaries in the Himalaya that marks the upper limit of the forest vegetation between 3300-3600 m in the Western Himalaya and 3600-4000 m in the Eastern Himalaya, and represents an ecotone between the subalpine and alpine zone. The timberline ecotone marks a gradual recession from close canopy forests to stunted forests or krummholtz along the increasing gradient of altitude and exhibits a sharp ecological gradient of biotic and abiotic components. This zone experiences the climate of temperate as well as alpine region and creates a large number of micro-habitats manifested by the action of snow, wind, topography, aspect and anthropogenic pressures. The changes in micro-habitat, such as compaction of soil, replacement of herbs with grasses of alpine meadows, and consequent increase in root growth, impede the growth of tree species above timberline (Singh \& Singh 1992) and enhance species diversity from adjacent and contrasting ecosystems in natural ecotones (Cooperrider et al. 1986).

Date of publication (online): 26 March 2010

Date of publication (print): 26 March 2010

ISSN 0974-7907 (online) | 0974-7893 (print)

Editor: D. Narasimhan

Manuscript details:

Ms \# 02121

Received 21 January 2009

Final received 15 August 2009

Finally accepted 15 March 2010

Citation: Rai, I.D., B.S. Adhikari \& G.S. Rawat (2010). A unique patch of timberline ecotone with three species of Lady's slipper orchids in Garhwal Himalaya, India. Journal of Threatened Taxa 2(3): 766-769.

Copyright: (c) Ishwari D. Rai, Bhupendra S. Adhikari \& Gopal S. Rawat 2010. Creative Commons Attribution 3.0 Unported License. JoTT allows unrestricted use of this article in any medium for non-profit purposes, reproduction and distribution by providing adequate credit to the authors and the source of publication.

Acknowledgements: The authors are thankful to the Director and Dean, Wildlife Institute of India for encouragements. Uttarakhand Forest Department is thanked for providing necessary permission and support in conducting field work. Thanks also due to Dr. P.K. Sahani and Mr. Gajendra Singh for helping us in various ways.

\section{OPEN ACCESS | FREE DOWNLOAD (C) (i) @口}

The alpine timberlines are climatically determined ecotones (Körner 1998) and considered particularly sensitive to altered temperature regimes (Theurillat \&

Guisan 2001). Thus, the predicted climate warming is expected to result in structural changes of tree composition as well as in the upward movement of timberline (Albrecht et al. 2002). Timberline shifts will influence regional and local climates, pedogenesis, mineralization, plant assemblages and animal population and overall biodiversity (IPCC 2006). Upslope advance of timberline due to increased seedling density, increased tree growth rate and change in growth form often correspond with increased temperature and collectively have been attributed to global climate change (Innes 1991). As elsewhere, Himalayan timberline is also expected to respond to the effect of global warming, the intensity of which is likely to be more severe towards higher latitudes and altitudes (Purohit 1991).

Several studies have been conducted on forest structure and functions of forest ecosystems and alpine meadows, while the timberline ecotone has not received adequate attention so far. The timberline in west Himalaya harbors many species of threatened flora (Taxus baccata sub sp. wallichiana, Podophyllum hexandrum, Skimmia laureola, Valeriana wallichii and Polygonatum verticillatum) and fauna (Musk Deer Moschus chrysogaster, Himalayan Tahr Hemitragus jemlahicus, Serow Capricarnis sumatraensis; and pheasants: Himalayan Monal Lophophorus impejanus, Koklas Pucrasia macrolopha and Western Tragopan Tragopan melanocephalus), where physiognomy and regeneration patterns of plants and food habits and habitat use pattern of animals and pheasants are governed by regional climate, will lead to significant change in demographic patterns of these sensitive species. Therefore, Wildlife Institute of India felt the need for long term monitoring with respect to climate change and anthropogenic pressures to address the issues in the event of climate change, the composition of most sensitive communities is likely to change, further anthropogenic disturbances can also increase the rate of species loss and create opportunities for the establishment of alien species and processes such as habitat loss, modification and fragmentation can potentially intensify the impact of climate change.

The genus Cypripedium L. (Orchidaceae), comprising 45 species and two varieties, has a holarctic distribution, ranging from the arctic circle in Alaska and Scandinavia, south to Honduras in Central America and the Himalaya (Cribb 1997; Pearce \& Cribb 2002). The species in this genus are commonly known as 'Lady's slipper orchids' and belong to the tribe Cypripedieae and the sub-tribe Cypripedinae. The Lady's slipper orchids are easily identified by their plicate leaves and flowers, having a 

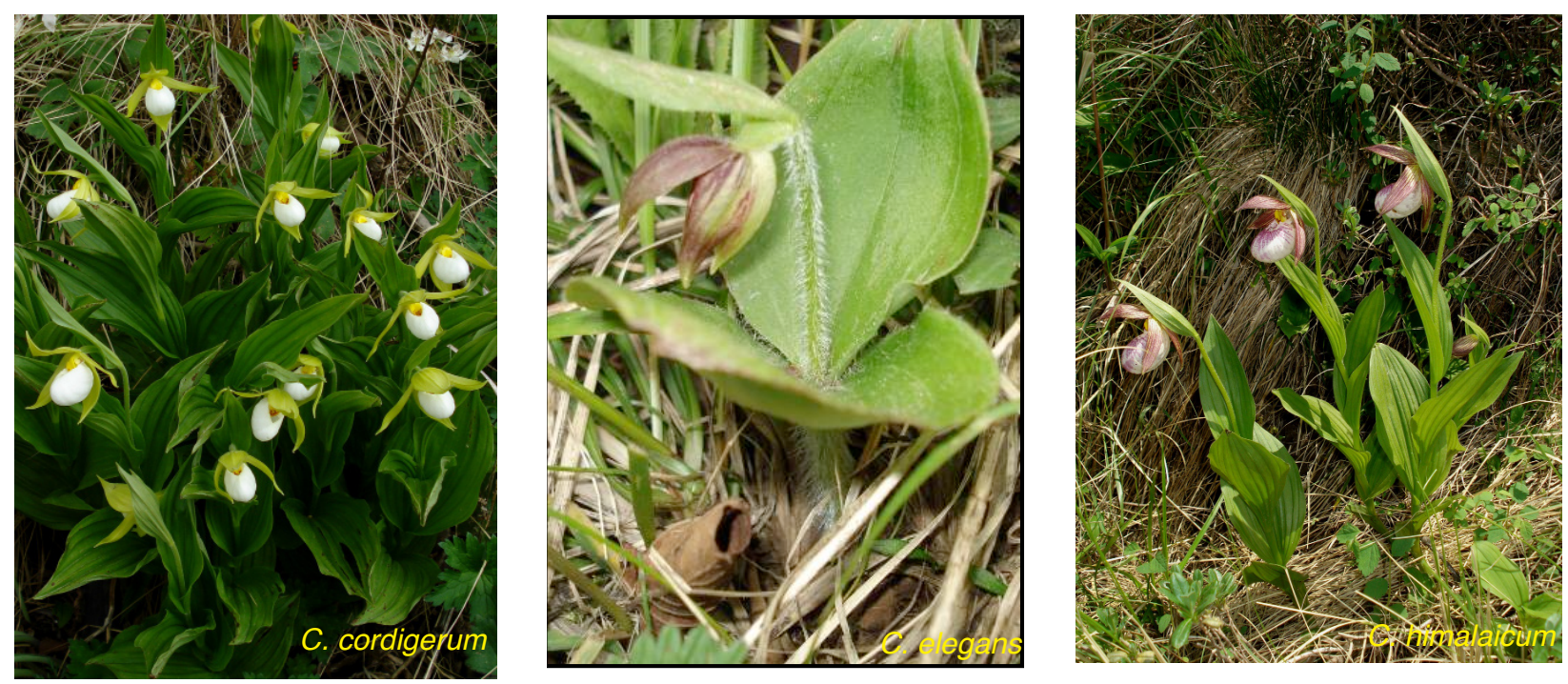

Image 1. Three species of Cypripedium in Kedarnath Wildlife Sanctuary, Garhwal Himalaya.

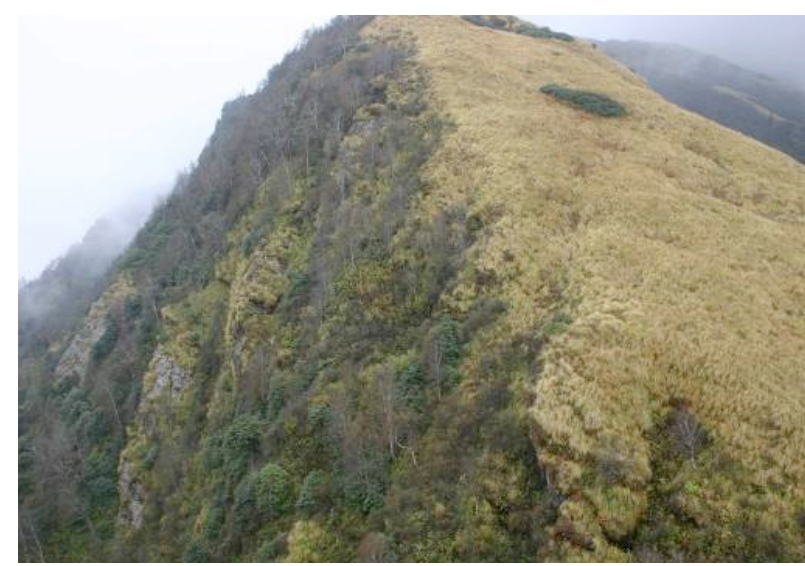

Image 2. An ideal habitat (Birch forest), of all Cypripedium spp. near Tungnath, Garhwal Himalaya

unilocular ovary, a slipper-shaped lip and a column with two fertile anthers and a sterile apical staminode. As with most terrestrial orchids, the rhizome is short and robust, growing in the uppermost soil layer. The rhizome grows annually with a growth bud at one end and dies off at the other end. The stem grows from the bud at the tip of the rhizome. These orchids have been cultivated in Europe for over four centuries. Despite difficulties to maintain them in cultivation their popularity has never decreased. They are the showy and most sought after orchids, collected and increasingly grown by orchid and alpine plant enthusiasts alike. They need specific microhabitat conditions for seed germination and propagation (Kull 1999). Wild populations are the major source of material for horticulture and medicine (Zhu 1989). As a result, the more accessible populations of many species have declined due to over collection. Habitat degradation due to excessive livestock grazing, logging, agricultural expansion and fire has also led to their decline. The current conservation status of the Asiatic species is poorly understood. However, all the species of Lady's slipper orchid are included in Appendix II of the Convention on International Trade in Endangered Species of Wild Fauna and Flora (CITES). Nearly half of the species of Cypripedium may be considered threatened and need immediate conservation action (Cribb \& Sandison 1998).

The genus Cypripedium is represented by three species in Western Himalaya, viz. C. cordigerum D. Don, C. elegans Reichb.f. and C. himalaicum Rolfe (Deva \& Naithani 1986; Jalal et al. 2008). These species are widely but sparsely distributed in the cool temperate and sub-alpine (2800-3500m) regions.

None of the plant explorers in the past have reported the occurrence of these species at a single locality. While collecting baseline information on the structure and composition of timberline vegetation at a timberline ecotone in outer fringes of Kedarnath Wildlife Sanctuary, we came across all three species of Cypripedium at a single site. This is the first report of these three species growing at a single locality. The three species and the site of their occurrence are shown in Images 1 \& 2, respectively. Significance of monitoring the timberline vegetation with special reference to populations of highly sensitive taxa is discussed.

The size of population for each species, micro-habitat features and information on associated plant taxa for the three species of Cypripedium have been compared in Table 1. It was found that $C$. elegans was distributed sporadically at the site but confined to the birch forest. However, C. cordigerum (two populations) and $C$. himalaicum (three populations) were more towards upper edge of the timberline. Cypripedium cordigerum has so far been reported from several localities between 2500-3000 $m$ in Western Himalaya (Deva \& Naithani 1986). However, the other two species viz., C. elegans and C. himalaicum are known to have wider altitudinal range, i.e. $2500-4000$ 
Table 1. Population parameters, micro-habitat features and taxa associated with three species of Cypripedium in birch forest

\begin{tabular}{|c|c|c|c|}
\hline \multirow{2}{*}{ Parameters } & \multicolumn{3}{|c|}{ Species } \\
\hline & C. elegans & C. cordigerum & C. himalaicum \\
\hline $\begin{array}{l}\text { Location and Number } \\
\text { of individuals }\end{array}$ & $\begin{array}{l}\text { Sporadic within entire patch (ca. } 190 \\
\text { individuals) }\end{array}$ & $\begin{array}{l}\text { Twelve patches (ranged from 5-40 } \\
\text { individuals) }\end{array}$ & $\begin{array}{l}\text { Three patches }(7+3+9) \\
\text { individuals) }\end{array}$ \\
\hline Micro-habitat features & $\begin{array}{l}\text { Shady places under birch and willow, } \\
\text { on slopes between } 25-52^{\circ}\end{array}$ & $\begin{array}{l}\text { Steep slopes }\left(>55^{\circ}\right) \text {, on rock } \\
\text { overhangs, open scrub of } R \text {. lepidotum, } \\
\text { partially exposed soil }\end{array}$ & $\begin{array}{l}\text { Steep grassy slopes (ca. } 50^{\circ} \text { ) } \\
\text { amidst Danthonia grass }\end{array}$ \\
\hline Associated species & $\begin{array}{l}\text { Smilacina purpurea, Viola biflora, } \\
\text { Fragaria nubicola, Gerbera sp., } \\
\text { Caltha palustris, Clematis sp., } \\
\text { Bergenia stracheyi, Ranunculus } \\
\text { hirtellus, Selinum vaginatum }\end{array}$ & $\begin{array}{l}\text { Danthonia cachemyriana, Anemone } \\
\text { tetrasepala, Rhododendron lepidotum, } \\
\text { Nardostachys jatamansi }\end{array}$ & $\begin{array}{l}\text { Danthonia cachemyriana, } \\
\text { A. tetrasepala, Aconitum } \\
\text { heterophyllum, R. lepidotum, N. } \\
\text { jatamansi }\end{array}$ \\
\hline
\end{tabular}

$m$ and $3000-4300 \mathrm{~m}$ respectively. Recent orchid surveys in the state of Uttarakhand reveals that most of the sites from where Cypripedium species were reported earlier, have degraded and the populations of these orchids have declined considerably (Jalal et al. 2008). Occurrence of $C$. cordigerum at an altitude of $3500 \mathrm{~m}$ at present site is quite interesting. Co-occurrence of all three species at one site implies that the micro-habitat conditions at the site are congenial for the growth of these species and vegetation structure as well populations of these three taxa. This site has yet another unique feature, i.e. co-occurrence of birch along with Rhododendron arboreum.

The ongoing timberline monitoring programme of WII had already selected this site for further monitoring of various parameters as it is relatively free from anthropogenic pressures. Populations of Cypripedium are now being added to the overall monitoring protocol. It is hypothesized that in the event of slight increase in mean ambient temperature caused due to global warming the birch and Rhododendron arboreum would shift upwards and populations of edge species especially $C$. himalaicum and $C$. cordigerum will be affected negatively.

The distribution of Cypripedium species in the Western Himalaya by several explorers is given in Table 2.

\section{References}

Albrecht, C., P. Baccini, A. Baranzini, M. Beniston, H. Bugmann, T. Bürki, S. Frankhauser, A. Fischlin, J. Fuhrer, Y. Gonseth, S. Güsewell, R. Hohmann, J. Jansen, F. Joos, W. Kägi, D.K. Keuerleber-Burk, N. Künzli, L. Oglesby, P. Previdoli, B. Schädler \& T. Stocker (2002). Das Klima ändert - auch in der Schweiz: Die wichtigsten Ergebnisse des dritten Wissenstandsberichts des IPCC aus der Sicht der Schweiz", Organe consultatif sur les changements climatiques (OcCC), Bärenplatz 2, CH-3011 Bern, 48pp.

Cooperrider, A.Y., R.J. Boyd \& H.R. Stuart (1986). Inventory and Monitoring of Wildlife Habitat. U.S. Department of the Interior, Bureau of Land Management, Denver, 858pp.

Cribb, P. (1997). The Genus Cypripedium. Timber Press, Inc. Portland, Oregon, 301pp.

Cribb, P. \& M.S. Sandison (1998). A preliminary assessment of the conservation status of Cypripedium species in the wild. Botanical Journal of Linnenean Society 126: 183-190.

Deva, S. \& H.B. Naithani (1986). The Orchid Flora of North-West Himalaya. New Delhi: Print and Media Associates, 459pp.

Innes, J.L. (1991). High altitude and high latitude tree growth in relation to past, present and future global climate change. Holocene 1: 168-173.

IPCC (2001). Climate Change 2001: Impacts, Adaptation and Vulnerability. Cambridge University Press, Cambridge, 1042pp.

Jalal, J.S., P. Kumar, G.S. Rawat \& Y.P.S. Pangtey (2008). Orchidaceae, Uttarakhand, Western Himalaya, India. Check List 4(3): 304-320.

Körner, C. (1998). A re-assessment of high elevation Timberline position and there explanation. Oecologia 115: 445-459.

Kull, T. (1999). Cypripedium calceolus L. Journal of Ecology 87: 913-924.

Pearce, N.R. \& P.J. Cribb (2002). The Orchids of Bhutan. Royal Botanic Gardens, Edinburgh, 643pp.

Purohit, A.N. (1991). Potential impact of global climate change in Himalaya, pp.591-604. In: Impact of Global Climate Changes on Photosynthesis and Plant Productivity. Oxford and IBH, New Delhi, 824pp.

Singh, J.S. \& S.P. Singh (1992). Forest of Himalaya. Gyanodaya Prakashan, Nainital, 292pp.

Theurillat, J.P. \& A. Guisan (2001). Potential impact of climate change on vegetation in the European Alps: A review. Climate Change 50: 77-109.

Zhu, Y.C. (1989). Orchidaceae, pp.182-185. In: Chang, Z.Y (ed.). Plantae Medicinales Chinae Bor. Orient., 484pp. 
Table 2. Collection of Cypripedium spp. from different locations in western Himalaya

\begin{tabular}{|c|c|c|c|c|}
\hline Species & District & Locality \& altitude (m) & Collector & Coll. No. \\
\hline \multirow{17}{*}{ C. cordigerum } & Dehradun & Jaunsar & Fischer & 1882 \\
\hline & \multirow{4}{*}{ Tehri } & Nagtibba, 2750 & Gollan & 2058 \\
\hline & & Bok Hills & Harsukh & 24153 \\
\hline & & Near Deota & Duthie & 19846 \\
\hline & & Nagtibba & J.S. Jalal & 13823 \\
\hline & \multirow{4}{*}{ Uttarkashi } & Tons Valley, Har-ki-Dun, 3500 & Deva & 6885 \\
\hline & & Below Syaure & Sahni & 24945 \\
\hline & & Janki Chatti, 2600 & Shetty & 35804 \\
\hline & & Jumnotri, 3100 & M.A. Rau & 15787 \\
\hline & Chamoli & Ghangharia, 3100 & M.A. Rau & 31744 \\
\hline & Nainital & Lariakanta, 2450 & Davidson s.n. & - \\
\hline & Bageshwar & Kurrain Pass, Pindar Valley & Strachey \& Winterbottom & 56 \\
\hline & Shimla & - & Gamble & $4340 G$ \\
\hline & \multirow{2}{*}{ Gulmarg } & - & Duthie & 11369 \\
\hline & & - & Inayat & 25398 \\
\hline & \multirow{2}{*}{ Rudraprayag } & Tungnath,3365 & I.D. Rai & 11406 \\
\hline & & Trijuginarayan, 2500-3000 & B.D. Naithani & 47985 \\
\hline \multirow{14}{*}{ C. elegans } & Uttarkashi & Sunapra, Kharsli & Deva & 4592 \\
\hline & \multirow{10}{*}{ Chamoli } & \multirow{3}{*}{ Valley of Flowers, 3400} & H.B. Naithani & 1025 \\
\hline & & & Renz & 13623 \\
\hline & & & Bhattacharya & 39082 \\
\hline & & \multirow{3}{*}{ Ghangharia, 3100} & H.B. Naithani & 1028 \\
\hline & & & Renz & 13624 \\
\hline & & & Bhattacharya & 39009 \\
\hline & & Bajmora & T.A. Rao & 10286 \\
\hline & & Hemkund & Bhattacharya & 39047 \\
\hline & & Dibrugeta to Deodi, $3700-3800$ & P.K. Hajra & 73237,73789 \\
\hline & & Dibrugeta (Nanda Devi NP), 3750 & B.S. Adhikari s.n. & - \\
\hline & Almora & Dugli & G.S. Rawat & 1608 \\
\hline & Pithoragarh & Near Marjhali on the way to Ralam & J.S. Jalal & 13933 \\
\hline & Rudraprayag & Tungnath, 3365 & I.D. Rai & 11427 \\
\hline \multirow{10}{*}{ C. himalaicum } & \multirow{2}{*}{ Uttarkashi } & Above Jhala, 3200 & Duthie & 192 \\
\hline & & Tons Valley, Har-ki-Dun, 3500 & Deva & 6910 \\
\hline & \multirow{4}{*}{ Chamoli } & \multirow{2}{*}{ Valley of Flowers, 3550} & H.B. Naithani & 1024 \\
\hline & & & Renz & 13622 \\
\hline & & Dibrugheta to Deodi, $3700-3800$ & P.K. Hajra & 73238,73788 \\
\hline & & $\begin{array}{l}\text { Dibrugeta \& Phari ki dhar (Nanda } \\
\text { Devi NP), } 3750\end{array}$ & B.S. Adhikari s.n. & - \\
\hline & \multirow{2}{*}{ Pithoragarh } & Byans & Duthie & 5994 \\
\hline & & Garbyang & G.S. Rawat & $1256(\mathrm{~A})$ \\
\hline & \multirow{2}{*}{ Rudraprayag } & Tungnath, 3365 & I.D. Rai & 11444 \\
\hline & & Kedarnath, 3800 & B.D. Naithani & 8703 \\
\hline
\end{tabular}

